\title{
Tax Competition: Global but Virgin under Rwandan Law
}

\author{
Pie Habimana*
}

Abstract

This paper's foundation is the global character of (harmful) tax competition. While this phenomenon's global existence is widely recognised alongside the global endeavours to fight against it, the situation in Rwanda seems not to be the same. That makes up the main purpose of this paper which aims to show how (harmful) tax competition constitutes a global issue, but with little attention under Rwandan law. In that regard, this paper calls the attention of Rwandan policymakers, academics, and researchers to dive deep in the matters of tax competition for the sake of making Rwanda stand on the safe side. This paper plays a role of a wake-up bell to step in other legal systems' concerns in the regulation of (harmful) tax competition.

\section{A. Introduction}

States' tax competition is one of the hottest topics that attracts the attention of lawyers. And not just for lawyers; it has also become a global topic ${ }^{1}$ classically debated in most parts of the world by politicians, economists, policymakers, commentators, academics, etc. ${ }^{2}$ International tax competition is also a key part of constantly and hotly discussed international

* Pie Habimana, Ph.D candidate in International Tax Law at Leiden University, Faculty of Law, Tax Law Department. Lecturer at University of Rwanda, School of Law. Senior Partner in Amilex Chambers. This paper is significantly based on the doctoral research that the author is currently engaged in at Leiden University (The Netherlands).

1 H G Petersen (ed), 'Tax Systems and Tax Harmonization in the East African Community' (2010) Report for the GTZ and the General Secretariat of the EAC, p. 24; M P van der Hoek, 'Tax Harmonization and Competition in the European Union' (2003) eJournal of Tax Research 1(1), 19.

2 L V Faulhaber, 'The Trouble with Tax Competition: From Practice to Theory' (2018) Tax L.Rev. 71(311), p. 311; F Wishlade, 'When Policy Worlds Collide: Tax Competition, State Aid, and Regional Economic Development in the EU' (2012) Journal of European Integration 34(6), p. 586; L Cerioni, 'Harmful Tax Competition Revisited: Why not a Purely Legal Perspective under EC Law?' (2005) Euro.Tax., p. 267; S Drezgić, 'Harmful Tax Competition in the EU with Reference to Croatia' (2005) Journal of Economics and Business 23(1), p. 72; M P Devereux and S Loretz, 'What do we Know about Corporate Tax Competition?' (2013) Nat'l Tax J. 66(3), p. 745. 
tax issues. ${ }^{3}$ Notwithstanding that, international tax competition constitutes a controversial area, which challenges academics to continue research in this area. ${ }^{4}$

The same situation underlies the context under which this paper was carried out. With a focus on Rwanda, this study lines up with existing international initiatives aiming at counteracting harmful tax competition. Building from scratch, the lack of deep academic legal research conducted on the Rwandan aspects of tax competition justifies the necessity of producing this research paper to cover the gap and build knowledge in the matter.

The production of this paper thrives on a legal doctrinal approach coupled with comparative legal research complements. Considered as the most dominant legal method in the legal world of research, ${ }^{5}$ the legal doctrinal approach in this paper has been desk-research and consisted of scrutiny, review, study, analysis, and synthesis of relevant literature pertaining to this paper topic. Regarding the complements of the comparative legal research approach, the European Union (EU) law and the instruments of the OECD (Organization for Economic Co-operation and Development) in matters of tax competition have been widely consulted. However, these have been referenced to not for the purpose of a comparative study per se, but for the sole purpose of reference, clarification, and inspiration.

That being the case, this paper pulls together the general situation of (harmful) tax competition vis-à-vis the Rwandan situation about the same matter. In that respect, this paper is subdivided into five sections, introduction and conclusion included. In a sequence, after the introductory section, the paper starts by understanding the phenomenon of tax competition. In the same vein, it proceeds to explaining how the phenomenon of tax competition raises out. Thereafter, it highlights the tax competition in a global view. Towards the conclusion, the Rwandan situation of tax competition is put at a glance along with demonstrating the mismatch between the global regulatory situation of tax competition and the Rwandan situation in the matter.

\section{B. Understanding (harmful) tax competition}

Before entering into the core matter of this paper, it is first important to simplify the understanding of tax competition. This is done in consideration of two aspects namely the definitional aspect and the developmental aspect of tax competition.

3 H Gribnau, 'The Integrity of the Tax System after BEPS: A Shared Responsibility' (2017) ELR 1, p. 12; OECD, Countering Harmful Tax Practices More Effectively Taking into Account Transparency and Substance: Action 5: 2015 Final Report, OECD/G20 Base Erosion and Profit Shifting Project, p. 3.

4 Faulhaber (n 2) p. 323.

5 T Hutchinson, 'The Doctrinal Method: Incorporating Interdisciplinary Methods in Reforming the Law’ (2015) European L.Rev. 3, p. 131. 
I. What is (harmful) tax competition?

The discussions over tax competition cascade through three main concepts namely the tax competition per se, harmful tax competition, and harmful tax practices. The three concepts are detailed below.

\section{Tax competition}

The introduction of the concept 'tax competition' is largely associated with C. Tiebout in $1956^{6}$ and it has several definitions. From a variety of available definitions, three elements are key in the definition of tax competition. These are the parties involved, the way tax competition is done and the reason of engaging in tax competition.

In an attempt to define tax competition, and without undermining economic consideration of local tax competition i.e. between municipalities or federations, it is evident that this phenomenon occurs between sovereign and independent states. ${ }^{7}$ In other words, tax competition is practiced by and between the governments of sovereign states. ${ }^{8}$ From this, the next point is how?

In engaging in tax competition, states use their tax-setting powers to work on their tax systems' features by trying to offer the most attractive and competitive tax environment. ${ }^{9}$ This is done by lowering the internal tax burden ${ }^{10}$ through tax rates or tax bases reduc-

6 N E Mitu, 'Tax Competition: Areas of Display and Effects' (2009) European Research Studies XII(2), p. 67.

$7 J$ Englisch and $A$ Yevgenyeva, 'The Upgraded Strategy against Harmful Tax Practices under the BEPS Action Plan' (2013) British L.Rev. 5, p. 621; C Pinto, Tax Competition and EU Law (Ph.D Thesis, University of Amsterdam 2002), p. 297-98; P J Wattel, 'Forum: Interaction of State Aid, Free Movement, Policy Competition and Abuse Control in Direct Tax Matters' (2013) WTJ, p. 138; A Renda, 'Reflections on the EU Objectives in Addressing Aggressive Tax Planning and Harmful Tax Practices' (2020) Final report to European Commission, p. $16<$ http://aei.pitt.edu/102 468/1/KP0419785ENN.en_.pdf> accessed 29 April 2020.

$8 R$ Teather, 'The Benefits of Tax Competition' (2006) IEA Hobart Paper No. 153, p. $25<\mathrm{https}: / /$ pap ers.ssrn.com/sol3/papers.cfm?abstract_id=878438\&download=yes $>$ accessed 03/08/2019; $A$ Semeta, 'Competitive Tax Policy and Tax Competition in the EU' (2011) Speech/11/712, $2^{\text {nd }}$ Taxation Forum of Diario Economico/OTOC, p. $3<$ file://C:/Users/HP/Downloads/SPEECH-11712_EN.pdf> accessed 14/08/2019; A P Morriss and L Moberg, 'Cartelizing Taxes: Understanding the OECD's Campaign against Harmful Tax Competition' (2012) CJTL 4(1), p. 5.

9 D M Ring, 'Democracy, Sovereignty and Tax Competition: The Role of Tax Sovereignty in Shaping Tax Cooperation' (2009) Fla.Tax.Rev. 9(5), pp. 561-62; Semeta, Id., p. 3; V Sobotková, 'Revisiting the Debate on Harmful Tax Competition in the European Union' (2012) Acta Universitatis Agriculturae et Silviculturae Mendelianae Brunensis 36(4), p. 344; C Pinto, 'EU and OECD to Fight Harmful Tax Competition: Has the Right Path Been Undertaken?' (1998) Intertax 26(12), p. 386.

10 Pinto, EU and OECD, Ibid.; Sobotková, Ibid., p. 344. 
tions. ${ }^{11}$ Even though interdependent, this is mostly, if not always, done in a strategic uncooperative way, by which each sovereign state determines its fiscal policy in disregard of other states' interests. ${ }^{12}$ Why is then this done?

The states' motivation in tax competition has been referred to when defining this phenomenon. The motivation has been described as being for the sake of gaining a large share of international tax base. ${ }^{13}$ To this end, attraction of investment, business, or economic activities, capital, and profits is very important and is often mentioned in attempts to define tax competition. ${ }^{14}$ Thus, a combination of the above three elements leads to defining tax competition as states' strategic practices to lower the internal tax burden for the sake of gaining a large share of international tax base through attraction of business.

\section{Harmful tax competition}

Closely associated to tax competition, is the concept of 'harmful tax competition'. Even though important, and contrary to tax competition per se, this concept has not been given many definitions. Even the key institutions that are generally considered as the pioneers of regulating the tax competition have expressed little interest in defining this concept. This applies to the OECD whose 1998 Report deals with harmful tax competition without precisely defining what it is. ${ }^{15}$ In fact, this Organization frankly admitted the absence of precise technical meaning of harmful tax competition. ${ }^{16}$ The same is true of the 1997 EU Code of conduct on business taxation. ${ }^{17}$ Yet, the two are internationally recognized for having played a pioneering role in the discussions and regulations of harmful tax competition.

11 Teather (n 8) p. 25; $M$ Wróblewska, 'Harmful Tax Competition in a Globalized World: Does the World Trade Organization Deal with this Issue?' (2016) Studia Iuridica 1, p. 15.

12 Englisch and Yevgenyeva (n 7) p. 621; B B Kristiaji, Incentives and Disincentives of Profit Shifting in developing Countries (Master Thesis, Tilburg University 2015), p. 12; P Dietsch, Catching Capital: The Ethics of Tax Competition (OUP 2015), p. 2 and 36; P Dietsch, 'Whose Tax Base? The Ethics of Global Tax Governance', in P Dietsch and T Rixen (eds), Global Tax Governance: What is Wrong with it and How to Fix it (2016), p. 232.

13 Pinto, Tax competition (n 7) pp. 297-98.

14 Englisch and Yevgenyeva (n 7) p. 621; D M Ring, 'What's at Stake in the Sovereignty Debate: International Tax and the Nation-State' (2008) Va.J.Int'Ll. 49(1), p. 21; Teather (n 8) p. 25; Semeta (n 8) p. 3; Sobotková (n 9) p. 344; Pinto, EU and OECD (n 9) p. 386; Wróblewska (n 11) p. 15; Renda (n 7) 16.

$15 B$ J Arnold and M J McIntyre, International Tax Primer (2 ${ }^{\text {nd }}$ ed., 2002), p. 138; G M Melo, 'Taxation in the Global Arena: Preventing the Erosion of National Tax Bases or Impinging on Territorial Sovereignty (A Critique of the OECD'S Report: Harmful Tax Competition: An Emerging Global Issue)' (2000) Pace International L.Rev. 12(183), p. 186 and 197.

16 OECD (1998), Harmful Tax Competition: An Emerging Global Issue, p. 20.

17 Wróblewska (n 11) p. 16; P Boria, Taxation in European Union (2 ${ }^{\text {nd }}$ ed., 2017), p. 166. 
Moreover, providing a precise definition of harmful tax competition has been described as impossible, ${ }^{18}$ to an extent that so far there is no agreed upon legal nor scientifically accepted definition of harmful tax competition. ${ }^{19}$ Even so, harmful tax competition has been synonymously termed and largely associated with tax poaching and/or tax piracy ${ }^{20}$ and it has been founded upon the tax havens and the harmful preferential tax regimes. ${ }^{21}$

Beyond that and leaning on the synonymous use with tax poaching, it becomes apparent that harmful tax competition is a negative continuation of tax competition. This understanding justifies embracing the definition that describes harmful tax competition as referring to a 'country's exploitation of the interaction of the tax systems by enacting special tax provisions which principally erode the tax base of other countries' ${ }^{22}$ Here, the main and most qualifying element is the erosion of other countries' tax bases which in one way or another transmits the same message as poaching other countries' taxes. Hence, harmful tax competition concerns tax provisions that erode other countries' tax bases but not their own tax base which remains intact.

\section{Harmful tax practices}

Besides harmful tax competition, there is also a concept of harmful tax practices. This concept is interchangeably used as harmful tax competition. The existence of the two interchangeable terms is mainly rooted in the OECD Reports. This Organization's 1998 Report used the concept harmful tax competition. It is within the 2001 Progress Report that the

18 Arnold and McIntyre (n 15) p. 138; C M Radaelli, 'Harmful Tax Competition in the EU: Policy Narratives and Advocacy Coalitions' (1999) JCMS 37(4), p. 672.

19 Wróblewska (n 11) p. 16; Faulhaber (n 2) p. 312 and 314; H Gribnau, 'Soft Law and Taxation: EU and International Aspects' (2008) Legisprudence 2(2), p. 76; O Pastukhov, 'Counteracting Harmful Tax Competition in the European Union' (2010) Sw.JIL 16, p. 161; C M Radaelli, 'The Code of Conduct against Harmful Tax Competition: Open Method of Coordination in Disguise' (2003) Public Administration 81(3), p. 522.

$20 M G$ Asher and $R S$ Rajan, 'Globalization and Tax System: Implications for Developing Countries with Particular Reference to Southeast Asia' (2001) ASEAN Economic Bulletin 18(1), p. 127; Pinto, EU and OECD (n 9) p. 390; M Ronzoni, 'Tax Competition: A Problem of Global or Domestic Justice?', in P Dietsch and T Rixen (eds), Global Tax Governance: What is Wrong with it and How to Fix it (2016), p. 204; Boria (n 17) p. 166; B J Kiekebeld, Harmful Tax Competition in the European Union, Code of Conduct, Countermeasures and EU Law, Deventer, Kluwer, 2004, 8-9 cited in C Biz, 'Countering Tax Avoidance at the EU Level after 'Luxleaks' A History of Tax Rulings, Transparency and BEPS: Base Erosion Profit Shifting or Bending European Prospective Solutions? (2015) DPTI XII(4), pp. 1039-40; E Traversa and P M Sabbadini, 'State Aid Policy and the Fight against Harmful Tax Competition in the Internal Market: Tax Policy Disguise', in W Haslener, G Kofler and A Rust (eds), EU Tax Law and Policy in the $21^{\text {st }}$ Century (2017), p. 111; $T$ Edgar, 'Corporate Income Tax Coordination as a Response to International Tax Competition and International Tax Arbitrage' (2003) CTJ/RFC 51(3), p. 1141.

21 I Calich, The Impact of Globalization on the Position of Developing Countries in the International Tax System (Ph.D Thesis, LSE 2011), pp. 59-60.

22 Pinto, EU and OECD (n 9) p. 340. 
OECD changed it to adopt the use of the concept of harmful tax practices. ${ }^{23}$ Even so, both concepts are still used today.

From the above, and without undermining a variety of initiatives dealing with tax competition, it is observable that this area is characterized by a paucity of definitions of the main concepts underlying it. For example, so far there is no agreed upon legal nor scientifically accepted definition of harmful tax competition. ${ }^{24}$ The same applies to its synonymous concept of harmful tax practices, whose definition is regarded as complex with no general agreement, academic or political. ${ }^{25}$ In this regard, it has been authored that harmful tax competition cannot be defined because it has no intrinsic meaning. ${ }^{26}$ The same is furthermore the case of the concepts of tax havens and harmful preferential tax regimes which so far have not yet got consistent definitions, apart from being considered as the constitutive elements of harmful tax competition as per the OECD 1998 Report.

In as far as the concept of tax havens is concerned, the OECD 1998 Report did not define it. This Report also expressly accepted that by stating that this concept has no precise technical meaning. ${ }^{27}$ The same absence of a technical meaning also applies to the concept of harmful preferential tax regimes. ${ }^{28}$ This is explicated by the fact that the factors which are used to identify them always change over the time, ${ }^{29}$ which also contribute to the complexities to effectively and clearly eliminate them. ${ }^{30}$ This has led to considering the attempts to define tax competition and harmful tax competition as multifaceted. ${ }^{31}$ Furthermore, that leads, in one way or another, to describing it with reference to the 'elephant test' and statements like 'you'll know one when you see it'. ${ }^{32}$ Unresolved, that paucity exists along with some other manifold discussions, among them the origination of tax competition.

\section{How does tax competition arise out?}

In the general principles of international law, states are entitled with sovereignty that entails them to run their internal affairs without interference. The principle of state sovereignty is widely enshrined in a number of international legal instruments such as the United Nations

23 Morriss and Moberg (n 8) p. 49.

24 Wróblewska (n 11) p. 16; Faulhaber (n 2) p. 312 and 314; Gribnau, Soft Law and Taxation (n 19) p. 76; Pastukhov (n 19) p. 161; Radaelli, The Code of Conduct (n 19) p. 522.

25 Englisch and Yevgenyeva (n 7) p. 622.

26 Faulhaber (n 2) p. 359.

27 Pinto, EU and OECD (n 9) p. 391; Calich (n 21) p. 60.

28 Calich, Id., p. 65.

29 Id., p. 204.

30 Id., p. 65.

31 Pastukhov (n 19) p. 163.

32 Ibid. 
Charter, ${ }^{33}$ the African Union Constitutive Act, ${ }^{34}$ the Treaty for the establishment of the East African Community (EAC), ${ }^{35}$ to mention just a few. State sovereignty as a concept is very large, both in theory and in practice. In one way or another, this enormity is due to a number of sovereignty's inner features that cut cross a wide range of domains such as political, military, economic, social, legal, etc.

In this respect, one of the state sovereignty's hallmarks is a state fiscal sovereignty. The latter has been regarded as the key element of the former to such an extent that it is thought of constituting its closest key part along with serving as its classical attribute. ${ }^{36}$ In simple terms, state fiscal sovereignty entails the state's right to design its own tax system. In doing so, the end aim is to set up a tax system that is most suitable for the country's particular traits and needs. This is mainly done to reflect the citizens' preferences taking into account the conflicting objectives of economy efficiency. ${ }^{37}$ To this, is added the consideration that every state, developed or developing, desires to attract as many as possible investments. ${ }^{38}$ Thus, the two considerations entail the states' consistent needs to ensure their respective competitiveness in international economic structures.

Therefore, for the sake of satisfying the latter, states design their tax systems with a vision of providing the most environment-friendly investment. Doing so, two main goals are paramount. One goal is to prevent the domestic businesses from flowing outside the national territory while the second is to attract foreign businesses to flow into the country. It is in this later context that the game of tax competition comes in.

Tax competition occurs between sovereign nations or territories which set the tax systems bidding for investments in an uncooperative way, each acting independently. ${ }^{39}$ It consists of lowering the tax burden for the sake of increasing the country's competitiveness, in turn of boosting the national economy. ${ }^{40}$ This is done mainly by setting favorable tax measures through the provision of preferential tax rates or preferential tax bases. In doing so,

33 The Charter of the United Nations, 1945, art. 2(1).

34 The Constitutive Act of the African Union, art. 3 and 4.

35 Treaty for the Establishment of the East African Community (As amended on 14/12/2006 and 20/08/2007), art. 6(1)(a).

36 A C Santos and C M Lopes, 'Tax Sovereignty, Tax Competition and the Base Erosion and Profit Shifting Concept of Permanent Establishment' (2016) EC Tax Review 5/6, p. 296; P Lampreave, 'Fiscal Competitiveness versus Harmful Tax Competition in the European Union' (2011) BFIT 65(6), p. 4; $J$ Li, 'Tax Sovereignty and International Tax Reform: The Author's Response' (2004) CTJ/RFC 52(1), p. 144.

37 Englisch and Yevgenyeva (n 7) p. 622.

38 A Sanni, 'Sovereign Rights of Tax Havens and the Charge of Harmful Tax Competition' (2011) $<$ www.thesait.org.za/news/96869/Sovereign-Rights-Of-Tax-Havens-And-The-Charge-Of-Harmful -Tax-Competition.htm> accessed 30/07/2019.

39 Englisch and Yevgenyeva (n 7) p. 621.

40 Pinto, Tax competition (n 7) p. 1. 
the main goal is the retention and attraction of capital investment. ${ }^{41}$ In this regard, all taxpayers stand as beneficiaries, ${ }^{42}$ which, along with increasing the national welfare, is not a bad thing when considered generally.

Put in another way, with tax competition, countries engage in a strategic competition, each trying to pull capital flowing into its jurisdiction along with protecting one's own tax base. To this end, a number of factors are used, including fashioning preferential tax regimes for foreigners, issues of secrecy rules, lax enforcement of existing rules, etc. ${ }^{43}$ In doing so, the endgame of such rules and practices is the creation of a comparatively advantaged environment.

Important to highlight is the fact that tax competition per se is generally not regarded as a problem. The problem arises when the situation escalates from good and desirable tax competition to harmful tax competition. The latter happens when states go beyond building a competitive tax system, i.e. by lowering the general tax burden for the sake of putting the general taxpayers in a tax-friendly environment, and seek to erode other states' tax bases through attracting highly mobile investment. In this circumstance, the target is the attraction of foreign business at the expense of other countries' economy. ${ }^{44}$ These maneuvers mostly go in hand with establishing ring-fenced regimes to protect their own tax bases on the detriment of other states' tax bases.

That being the case, and without deviating from the above, the occurrence of tax competition phenomenon can also be seen through the lens of its global characteristics. This is developed in the paragraphs below.

\section{The global view of tax competition}

From the literature, tax competition is described as a long-time phenomenon. Some of its tools are traced back in ancient histories to during the antiquity and middle age periods. ${ }^{45}$ Similarly, tax competition is viewed as an inevitable, natural and necessary phenomenon in consideration of the international tax systems structure. ${ }^{46}$ The international tax competitive-

41 I Roxan, 'Limits to Globalization: Some Implications for Taxation, Tax Policy, and the Developing World' (2002) LSE WP 3, p. 2 <http://eprints.lse.ac.uk/46768/1/Limits\%20to\%20globalisation $\% 2$ 0 (lsero).pdf $>$ accessed 07/05/2019.

42 Pinto, Tax competition (n 7) p. 1.

43 P Dietsch and T Rixen, 'Tax Competition and Global Background Justice' (2014) The Journal of Political Philosophy 22(2), p. 153.

44 Pinto, Tax competition (n 7) p. 1.

45 G A McCarthy, 'Promoting a More Inclusive Dialogue', in R Biswas (ed), International Tax Competition: Globalization and Fiscal Sovereignty (Commonwealth Secretariat 2002), p. 36; $\mathrm{D} \mathrm{Ka}$ manzi, 'De quel type de zone franche le Rwanda a-t-il besoin?' (1999) L.Rev. 3, p. 55.

46 Faulhaber (n 2) p. 312 and 321. 
ness has been also described as an increasingly important element of state economic life. ${ }^{47}$ Not only that, but also tax competition is widely recognized as a global phenomenon.

The global characterization of tax competition is justified by its presence everywhere, from developing countries to developed countries. As a matter of illustration, starting with existence of tax competition in developed countries, issues of harmful tax competition have been frequently tabled in European Union summits as they exist and continue to intensify in EU Member States. ${ }^{48}$ Europe has been also said to experience the race to the bottom along with a notice of an insurgence of the preferential tax regimes in the 1980s and 1990s. ${ }^{49}$ In addition, the European Union Code of conduct on business taxation acknowledged the EU Member States' engagement in (harmful) tax competition, therefore, presenting a need to curtail it. ${ }^{50}$ Equally, the 1998 Report of the OECD on harmful tax competition recognizes the existence of (harmful) tax competition in Organization members and non-members. ${ }^{51}$

From the perspective of developing countries, an example may be taken from the East African Community. In 2012, the Community's Legislative Assembly (EALA) admitted the engagement in tax competition by the Partner States, one against each other. ${ }^{52}$ By the same token, a Memorandum of Understanding (MoU) signed between the members of the Southern African Development Community (SADC) containing a clause on avoiding harmful tax competition signals the Community's awareness and acknowledgement of that practice realities. ${ }^{53}$ Some African countries also have been pointed out to have preferential tax regimes such as Mauritius' headquarter company regime, South Africa's headquarter company regime, Botswana's intermediary holding company regime, Liberia's shipping regime, etc. ${ }^{54}$ All these examples indicate, among others, how (harmful) tax competition exists in both developed and developing countries.

47 J Bossons, 'International Tax Competition: The Foreign Government Response in Canada and other Countries' (1988) Nat'l Tax J. 41(3), p. 347.

48 Pinto, Tax competition (n 7) p. 25; Pastukhov (n 19) p. 166; Radaelli, Harmful Tax Competition (n 18) p. 675.

49 Lampreave (n 36) p. 4; Morriss and Moberg (n 8) p. 36.

50 EU Code of Conduct 1997: Conclusions of the ECOFIN Council meeting of 1/12/1997 concerning taxation policy DOC 98/C2/01, OJEC (6.1.98) C 2/1; Pinto, Tax competition (n 7) p. 166.

$51 O E C D$ (n 16) p. 3 and 7; B Persaud, 'The OECD Harmful Tax Competition Policy: A Major Issue for Small States', in R Biswas (ed), International Tax Competition: Globalization and Fiscal Sovereignty (Commonwealth Secretariat 2002), p. 23.

$52 E A C, 2^{\text {nd }}$ Meeting of the $1^{\text {st }}$ Session of the $3^{\text {rd }}$ East African Legislative Assembly, Oral Answers to Priority Questions, Question: EALA/PQ/OA/3/06/2012, Nairobi, 13/09/2012, p. 10.

$53 S A D C$, Memorandum of Understanding on Cooperation in Taxation and related matters, 08/08/2002, art. 4(3)(a); Z C Robinson, Tax Competition and its Implications for Southern Africa (Ph.D Thesis, University of Cape Town 2002), p. 267.

54 A W Oguttu, 'International tax competition, Harmful tax practices and the 'Race to the bottom': a special focus on unstrategic tax incentives in Africa' (2018) CILJSA 51(3), pp. 299-302. 
Furthermore, in the last three decades, projects have been undertaken on tax competition topics. Hotly debated in the EU starting in the $1990 \mathrm{~s},{ }^{55}$ tax competition topics have attracted considerable attention on international forums. ${ }^{56}$ Similarly, tax competition issues have been internationally discussed and tabled in a number of scientific conferences and political meetings ${ }^{57}$ along with headlining the media as well. ${ }^{58}$ Addressing tax competition has also become a global concern with high priority, which has caused the involvement of many states along with other actors and initiatives. ${ }^{59}$ Examples of the momentous projects that cascaded down the last decades include, but are not limited, to ECOFIN Council Conclusions meeting of the 01 December 1997 on Code of conduct on business taxation, the OECD Project that ended with the 1998 Report on harmful tax competition, and the OECD/G20 BEPS Project with its report of 2015.

International tax competition has also attracted the attention of legal scholarship over decades, and still today, the topic has interest. Tax competition has also been mentioned in a large number of scientific articles ${ }^{60}$ to an extent that research on this topic has been considered as having boomed the academic business and this remains unabated. ${ }^{61}$ The importance of this topic in academic research is further evidenced by a number of scholarly publications dating back over three decades ${ }^{62}$ while others are very recent. ${ }^{63}$ All these elements

55 Gribnau, Soft Law and Taxation (n 19) p. 76 and 81; B I Bai, 'The Code of Conduct and the EU Corporate Tax Regime: Voluntary Coordination without Harmonization' (2008) Journal of International and Area Studies 15(2), p. 118.

56 Wishlade (n 2) p. 586.

57 Cerioni (n 2 ) p. 267; Radaelli, Harmful Tax Competition (n 18) p. 675.

58 Radaelli, Id., p. 662; Faulhaber (n 2) p. 332; D M Broekhuijsen, A Multilateral Tax Treaty: Designing an Instrument to Modernize International Tax Law (Ph.D Thesis, Leiden University 2017), p. 1; M Nouwen, 'The European Code of Conduct Group Becomes Increasingly Important in the Fight against Tax Avoidance: More Openness and Transparency is Necessary' (2017) Intertax 45(2), p. 139.

59 S Leviner, 'The Intricacies of Tax and Globalization' (2014) CJTL 5(207), p. 223; J McLaren, 'The OECD’s Harmful Tax Competition Project: Is it International Tax Law' (2009) Austl.Tax.F. 24, p. 423.

$60 \mathrm{~J}$ Hey, 'Tax Competition in Europe: The German Perspective' (EATLP Conference, Lausanne, 2002), p. $2<$ www.eatlp.org/uploads/Members/Germany02.pdf> accessed 13/08/2019.

61 T Rixen, 'Taxation and Cooperation: International Action against Harmful Tax Competition', in S A Schirm (ed), Globalization: State of the Art and Perspectives (Routledge 2007), p. 62; J D Wilson, 'Theories of Tax Competition' (1999) Nat'l Tax J. 52(2), p. 269; Devereux and Loretz (n 2) p. 745.

62 Bossons (n 47); B L Benson, 'Interstate Tax Competition, Incentives to Collude, and Federal Influences' (1990) Cato Journal 10(1); H-W Sinn, 'Tax Harmonization and Tax Competition in Europe' (1990) National Bureau of Economic Research WP 3248.

63 Faulhaber (n 2); I O Ozai, 'Tax Competition and the Ethics of Burden Sharing' (2018) Fordham Int'lL.J. 42(1); M C Durst, 'Poverty, Tax Competition, and Base Erosion' (2018) Tax Notes International 89(12); F G Morina, 'The Legal Aspect of the Tax Competition in EU: Case of Kosovo' (2019) Sriwijaya L.Rev. 3(1). 
demonstrate to what extent (harmful) tax competition is not a new issue rather a globally happening phenomenon with a set of globally counteracting measures.

On a separate but close note, and without undermining the long existence of tax competition, the problem of (harmful) tax competition has been intensified, more or less, by globalization, starting from the 1980s-1990s. It is at this time that tax competition became a concern for more countries. ${ }^{64}$ In fact, among other changes it brought with it, globalization has facilitated the free movement of capital and persons. With the easy movement of capital, it has been subsequently much easier for the states to strategize, each seeking to take a large share in the structure of the international tax base. Playing the same game in a process of retaliation, the states end up harming each other. Similarly, the countries end up with a spill-over situation of their peers' policies. Thereby, some of the harmful consequences thereto attached become inevitable. These include but are not limited to the significant erosion of the tax revenues, which end up creating a situation of fiscal degradation characterized by the states' inabilities to cater for public services.

In front of that situation, it becomes evident that the states could not stay inactive. In this regard, it has been rightly said that

States could not stand back while their tax bases are eroded through the actions of countries which offer taxpayers ways to exploit tax havens and preferential regimes to reduce the tax that would otherwise be payable to them. ${ }^{65}$

The above consideration, therefore, triggered the states, among other international tax actors, to engage in fights against harmful tax competition. In consideration of the international character of harmful tax competition, the evident assertion is that multilateral measures are more effective than unilateral measures. This thinking justifies the active involvement of international or regional institutions in such endeavors. This is exemplified by the active role played by the EU and the OECD, respectively at European and developed countries levels.

Even so, it is fascinating to observe a big difference between the focus of developed countries on (harmful) tax competition compared to developing countries. In fact, when it comes to developing countries, this area appears to have received very little attention. This is evidenced by a low engagement in the development of measures and practices counteracting harmful tax competition as is the case in the developed countries. In this vein, contrary to developing countries, most of the international initiatives to counteract the negative effects of tax competition have been so far undertaken by developed countries or through organizations whose members are developed countries. This is the case of OECD instruments and EU rules on the fight against harmful tax competition.

64 Faulhaber, Id. p. 326.

65 OECD (n 16) p. 37; K van Raad, Materials on International \& EU Tax Law (13 ${ }^{\text {th }}$ ed., 2013), p. 1323. 
In the same vein as the above, the concept of harmful tax competition has, for instance, been described as uncommon in EAC Partner States, ${ }^{66}$ and the low level of engagement is typical of the EAC Partner States, Rwanda included. Mindful of the general trend that prevails in developing countries, when it comes to Rwanda the situation becomes more exacerbated. This is illustrated by a paucity of research conducted on the Rwandan aspects of harmful tax competition, among others.

\section{The Rwandan situation of tax competition and issues thereto related}

With a particular focus on Rwanda, since 1994, Rwanda initiated a variety of programs aimed at boosting economic development and growth, with a targeted goal of moving the country from low income countries to middle income countries. Such programs include Vision 2020, Vision 2050, Economic Development and Poverty Reduction Strategies (EDPRS), Vision Umurenge Program (VUP), just to mention a few. Some of these programs are associated, in one way or another, with fiscal policies in the broad context of development. For instance, Vision 2020 recommends a development of effective strategies to expand the tax base and attract foreign investors as one of the ways to reduce dependency on foreign aid. ${ }^{67}$

Along the same lines of boosting economic development, strategies have been put in place to improve the competitiveness of Rwanda with a view to make the country appear among the top business-friendly jurisdictions. In this approach, the attraction of Foreign Direct Investment (FDI) is a blatant goal. To this end, Rwanda modernized its commercial laws and commercial disputes resolution systems, all for the sake of facilitating a safe investment climate open to foreign investors. ${ }^{68}$ Consequently, leaning on peace, security and political stability, Rwanda managed to improve its economic potential and made itself the highest ranked in the Ease of Doing Business Index in the EAC. ${ }^{69}$

Alongside this, Rwanda has also been improving the competitiveness of its tax system. It is in this respect that the laws pertaining to business taxation have been undergoing consistent changes. This basically concerns the income tax laws and the investment promo-

66 B C Kagyenda, 'Development of an EAC Model Agreement for the Avoidance of Double Taxation and an EAC Code of Conduct against Harmful Tax Competition', Final Report, EAC Secretariat GIZ EAC Tax Harmonization Project, Arusha, p. 11.

67 Republic of Rwanda, Ministry of Finance and Economic Planning, Rwanda Vision 2020, Kigali, Jul. 2000, p. $11<$ www.sida.se/globalassets/global/countries-and-regions/africa/rwanda/d402331a.p df $>$ accessed 24/10/2016; Republic of Rwanda, Rwanda Vision 2020, revised edition 2012, p. 6 $<$ www.minecofin.gov.rw/fileadmin/templates/documents/NDPR/Vision_2020_.pdf $>$ accessed $24 / 10 / 2016$.

68 N Huls, 'Constitutionalism à la Rwandaise', in M Adams, A Meuwese and E H Ballin (eds), Constitutionalism and the Rule of Law: Bridging the Idealism and Realism (2017), pp. 197-98.

69 Id., p. 218; World Bank, Easy of doing business Index $2018<$ https://data.worldbank.org/indicator/ IC.BUS.EASE.XQ> accessed 21/08/2019. 
tion and facilitation laws. Currently, these two laws ${ }^{70}$ are highly significant to investors considering a number of favorable tax measures therein.

Even though, from a legal research perspective, and in as far as Rwanda is concerned, the study of (harmful) tax competition appears to have received more little attention. This is epitomized by the paucity of available legal literature on this topic. However, Rwanda is not an island in the matters of harmful tax competition. This means that Rwanda may, to a given extent, be engaged in harmful tax competition with related fiscal externalities. Therefore, this pertaining situation justifies the significant need to undertake a legal study to clarify the situation in Rwanda, in the matters of (harmful) tax competition, among others.

Besides that paucity, a number of reprimanding reports, mainly from the non-governmental organizations, have been indicating how Rwanda is largely engaged in tax competition. ${ }^{71}$ However, it is unfortunate that such reports did not distinguish tax competition, which is good and desirable, from harmful tax competition, which is bad, undesirable, and condemnable. More of that, most of, if not all, these reports have been economic oriented. In this regard, the main concern has been the calculation of how much revenues are lost as a consequence of tax incentives offered to foreign investors. In other words, the key focus has been on the economic measurement of the fiscal degradation as a consequence of tax competition, while the legal aspect has been frozen out.

Thus, without neglecting the importance of such figures, the key legal issue remains on whether Rwanda is violating any regional or international legal rule in the matter. In other words, what has not been clarified so far, is whether Rwanda has kept itself within the margins of acceptable tax competition. In this respect, the Rwandan law remains with a number of the questions that are not yet responded, and which need to be responded. Such are for instance the determination of the current state of affairs of favorable tax measures under Rwandan law. There is also a need to determine the conventional benchmarks that can be used to identify harmful tax practices under Rwandan law. Equally, it is of paramount interest to determine to what extent the currently available favorable tax measures under Rwandan law are actually or not harmful. In the same vein, a search of proposals that can be designed to safeguard Rwanda from engaging in harmful tax practices also looks very important.

70 Law No. 016/2018 of 13/04/2018 establishing taxes on income, O.G. No. 16 of 16/04/2018; Law No. $06 / 2015$ of 28/03/2015 relating to investment promotion and facilitation, O.G. No. special of 27/05/2015.

71 P Abbott et al., 'The Impact of Tax Incentives in East Africa: Rwanda Case Study Report' (2011) IPAR; Tax Justice Network \& ActionAid, 'Tax Competition in East Africa: A Race to the Bottom?' (2012) Nairobi; Tax Justice Network \& ActionAid, 'Tax Incentives for Investors: Investment for Growth or Harmful Taxes?' (2011) Policy Brief on Impact of Tax Incentives in Rwanda; D Malun$d a$, 'Corporate Tax Incentives and Double Taxation Agreements in Rwanda: Is Rwanda getting a Fair Deal? A Cost Benefit Analysis Report' (2015) IPAR; ActionAid \& IPAR, 'Corporate Tax Incentives in Rwanda: Strategic Allocation of Tax Incentives to promote Investment and Self-Reliance in Rwanda' (2015) Policy Brief, p. 1. 
That being the case, it becomes conclusive that the study of tax competition from a legal perspective stands as a neglected area under Rwandan law. This is the case when this phenomenon has acquired a global character. That translates a mismatch between the Rwandan situation of tax competition regulatory framework and the general regulatory framework of tax competition.

Yet, considering the international aspect of harmful tax competition, each national tax system is unavoidably conditioned by other states' tax sovereignties. ${ }^{72}$ These fiscal externalities ${ }^{73}$ allow no single state to be shielded from spill-over effects of other states' tax policies. The same understanding has been voiced by the OECD in its 2000 Progress Report as follow:

Harmful tax competition is by its very nature a global phenomenon and therefore its solution requires global endorsement and global participation. Countries outside the OECD must have a key role in this work since a number of them are either seriously affected by harmful tax practices or have potentially harmful regimes. ${ }^{74}$

From that perspective, the current neglectful situation of Rwanda risks to have two potential results. Either, it can be construed as a will to engage in harmful tax competition as it can result into un-acquainted spill-over of harmful tax competition effects. Alternatively, the situation may be interpreted as being a result of low technical capacity in the matters of tax competition, among others. Whichever is the case, none is desirable, reason of calling upon Rwandan policymakers and legal researchers to conduct deep studies over the theories, principles, and practices of tax competition contextualized to the Rwandan circumstances.

\section{E. Conclusion}

In a summative view, this paper aimed at highlighting the current situation of Rwandan law amidst the global endeavours of counteracting harmful tax competition. In that regard, the departure has been a brief understanding of this phenomenon, through its conceptual framework and its developmental occurrence. Thereafter, it has been demonstrated how tax competition stands as a global phenomenon. This has been aligned with the situation of this phenomenon under Rwandan law. The main concern here has been the mismatch between the global situation and the Rwandan situation. In that regard, a call has been made to Rwandan policymakers and legal researchers to endeavour in studying this area for the sake

72 Lampreave (n 36) p. 4.

73 Wilson (n 61) p. 272; J M Mintz and M Smart, 'Recent Developments in Tax Coordination: A Panel Discussion by Bev Dahlby, Robert Henry, Michael Keen, and David E. Wildasin' (2000) CTJ/RFC 48(2), p. 400.

74 OECD (2000), Towards Global Tax Co-operation: Progress in Identifying and Eliminating Harmful Tax Practices, Report to the 2000 Ministerial Council Meeting and Recommendations by the Committee on Fiscal Affairs, p. 22. 
of limiting the consequences that are associated with harmful tax competition, namely avoiding being affected by harmful tax practices along with standing safe from having potential harmful tax competition regimes. 